\title{
The Impact of Leader-Member Exchange Towards Subordinate's Job Satisfaction in Bank X
}

\author{
Hanna Christina Uranus ${ }^{1}$ P. Tommy Y. S. Suyasa ${ }^{1 *}$ \\ ${ }^{1}$ Master of Psychology Program, Faculty of Psychology, Universitas Tarumanagara, Jakarta 11440, Indonesia \\ *Corresponding author. Email: tommys@fpsi.untar.ac.id
}

\begin{abstract}
Job satisfaction is defined as a content emotional state resulting of values and facilitations through employee's working experience. It is an important concept to study due to it's impacts towards employees and the organization as a whole. In the working place, employees are categorized into leaders and subordinates. The relationship between leaders and subordinates can be explained through a concept called leader-member exchange, and was found to have impact towards subordinate's job satisfaction. This research is purposed to understand the impact of leader-member exchange towards subordinate's job satisfaction at Bank X. The participants include 149 pairs of leader-subordinate and was reached through purposive sampling. As a result, we found that there is a direct impact of leader-member exchange towards subordinate's job satisfaction, and is correlated towards job satisfaction's dimensions as follows: (a) social extrinsic rewards $(0.282, \mathrm{p}<0.01)$; (b) intrinsic rewards $(0.237, \mathrm{p}<0.01)$; dan (c) organizational extrinsic rewards $(0.217,0<0.01)$. Other than that, the descriptive results indicate that the level of leader member exchange and subordinate's job satisfaction are considered high. Discussions and insights are also discussed in the last chapter of this paper.
\end{abstract}

Keywords: Leader-member exchange, job satisfaction, bank employee

\section{INTRODUCTION}

Banking industry in Indonesia has an increasing growth and becomes more competitive as most bank firms are trying to win customers. The competition within banking firms in Indonesia can be seen from Data Statistik Perbankan Indonesia, which shows that there are 4 kinds of Perseorangan Terbatas Banks (Persero banks), 49 BUSN (Bank Umum Swasta Nasional/ Private National Bank) devisa banks, 28 BUSN (Bank Umum Swasta Nasional/ Private National Banks) non-devisa banks, 26 BPD, 11 mixed bank firms, dan 10 foreign bank firms. With the data we received, it can be concluded that there were 118 kinds of bank firms operating, with the amount of 20.384 physical offices [1]. The existence of bank firm competitiveness can be considered as a good stimulus which will stimulate efficiency in the banking industry (bank firms will develop their own unique strengths) [2].

In order to survive through the competitiveness within banking firms, a certain bank firm should strive for the best and develop the right programs and policies to fulfill the needs of customers. Bank firms should offer significant advantages for customers [2]. Undang-Undang Republik Indonesia Nomor 10 Tahun 1998 stated that, in order to survive though the national economic growth with simultaneously growing challenges and adjusting national policies, economic firms (including the banking industry) should regularly evaluate and adjust their programs and policies.
Bank firms that are perceived as trustworthy (according to customers) are firms that have sympathy for customers [3][4][5]. Regarding that urgency, the subordinate's job satisfaction was found to have a significant impact on the bank's service quality [2]. In other words, subordinates are very important resources that have a significant role in the bank's growth, and their emotional state is a very important matter to put attention into [6].

One of the operating bank firms in Indonesia is Bank X, and has been operating since the early 1990s. Bank X strives for professionalism and trustworthiness, and has a motto to put customers' needs as the top priority in their work. Bank X's employees consist of 300 leaders and 1500 subordinates. Therefore, Bank X consists of 1800 employees in total (S., personal communication, 1th October 2018).

In Bank X, there is a phenomenon that takes form in content and not-content reaction from the employee's subordinates. Some factors that might contribute to their content reactions are rewards from the firm, warm and supportive environment in the workplace, and a close relationship, even with the leaders (L., personal communication, 14th November 2018). In addition, there are other facilities offered to employees, such as health insurance, education and developmental programs, and competence coaching. Bank X also provides promotion and additional benefits for top performing subordinates (S., personal communication, 21th January 2019). Other factors that contribute to their non-content reactions are rigid work culture, high and irrational level of achievement target, which they often have to reach in a rush with tight deadlines (C. \& L., personal 
communication, 14th November 2018). Some foreign leaders in the firm often treat them in an unfriendly manner, and employees perceive the compensation as lower, compared to other competing bank firms (S., personal communication, 30th September 2018).

Based on the observed phenomenon, content and noncontent reaction from employees can be explained through a psychological concept, known as job satisfaction. Job satisfaction is defined as a pleasant emotional state for achieving facilities or important values for the employee. Job satisfaction is also explained as a collective evaluation of many work aspects someone perceived [7]. Job satisfaction includes reaction or attitude cognitively, affectively, and evaluatively as a result of someone's experience and appraisal in their work [8]. Factors that are components of job satisfaction are the process of employee's decision making, the value perceived of their work, possibility of career promotion, decent resources for work, and a work responsibility that is realistic according to the employee's capabilities. Dimensions that form the job satisfaction are: (a) intrinsic rewards; (b) organizational extrinsic rewards; (c) social extrinsic rewards; (d) convenience extrinsic costs [9].

Employees who experience job satisfaction will perform their work more productively. Job satisfaction is positively correlated with work performance [10]. Leaders in Bank X also confirm that employees who experience job satisfaction are observed to have better work performance (S., personal communication, 1 October 2018). Employee's job satisfaction also correlates positively with consumer's satisfaction [11], and employee's retention [12][13]. There's a direct effect of job satisfaction on work commitment [14], correlates negatively with absenteeism [15], which was confirmed by a leader on Bank X (S., personal communication, 1 October 2018). Other than that, employees who experience job satisfaction will behave more obediently and proactively [16][17].

\subsection{Related Work}

There were previous researches that study job satisfaction which all confirmed that job satisfaction is predicted by another psychological concept, known as leader-member exchange [18][19][20]. Leader-member exchange is a dyadic condition between leader-subordinate, and includes the action of exchanging material (money) and non-material (information, affection) aspects [21].

Even though previous researches has found the correlation between leader-member exchange and job satisfaction [18][19][20], it has not stated the correlation with specific dimensions of job satisfaction [15]. Researches on job satisfaction that are specified on specific dimensions, rather than a general unidimensional measure, will be far more effective to apply and measure concretely at the real-life working place. Other than that, participants on the previous researches [18][19][20] are analyzed from a wide variety of contract and working types. Previous researches [18][19][20] also has not studied the subordinates specifically in a bank firm. In instance, we cannot conclude the previous conclusions on bank employees in Bank X, for they have different job descriptions and stressors.

On a previous research about leader-member exchange and job satisfaction [19], participants were from Hongkong which has its own specific work culture, and thus cannot be generalized to participants from Indonesia. Hongkong and Indonesia have cultural differences, for example in the way a decision is made. In Hongkong, participants accept some controversial policy as a support for the greater cause for a larger group of individuals, meanwhile Indonesian participants perceive it as a result of the decision maker's personal factors [22]. Therefore, different cultures will perceive how a decision was made in a different way [23]. Different perceptions of decision making also correlates significantly with job satisfaction [24][25][17]. In conclusion, the result from previous research cannot be generalized into subordinate form Bank X in Indonesia for different participant's backgrounds.

Previously used measurement instrument of job satisfaction does not focus on individual differences of values. It is important to consider this individuality, job satisfaction is an emotional statement and will be differently perceived by different individuals. Some measurement instrument that has been used before are Job Descriptive Index, and another independently developed measurement instruments [26][27]. All of them have many dimensions, but still do not cover the importance of individuality on urgency from that certain individual. Individual urgency was found to be significantly correlated to the level of job satisfaction [28][7]. With that being said, job satisfaction that is measured without considering individual urgency will be less comprehensive [9]. Considering the individual differences on an individual's urgency, the participant shall experience job satisfaction that varies from one another [7]. Another argument for the previous researches [18][19][20] is that they measured leader-member exchange as an unipolar concept. Meanwhile, leader-member exchange is defined as a dyadic relationship, and therefore should be considered from both the perspective of the leader and also the subordinate, thus considering the agreement perceived between both parties [29][17].

The relation between leader-member exchange and job satisfaction can be explained through a psychological concept called social exchange theory [30][31]. Social exchange theory is defined with the act of exchange in material (money) and non-material (affection, appreciation) components [32]. The dyadic exchange between leader and subordinate is very important in interaction especially makes it easier for subordinates to do their work with the assistance from their leader [33]. The advantage of social exchange does not exist only for subordinates, but also for the leader. Social exchange will give advantage on resources, and as a result that is being exchanged in the interaction. Thus, social exchange theory is able to explain the relationship between leader-member exchange and job satisfaction [31]. 


\subsection{Our Contribution}

Theoretically, this research will comprehend the previous researches about leader-member exchange and job satisfaction [18][19][20] Hopefully, this research can be considered as a source for future researches regarding leader-member exchange and job satisfaction. Practically, this research is hoped to be a resource for identifying the impact of leader-member exchange towards job satisfaction, which is beneficial for both employees and organization. Benefits of job satisfaction are summarized as follows: (a) better subordinate's work performance; (b) better subordinate's retention; (c) higher level of organizational citizenship behavior; (d) increasing productivity and benefit of the organizational institution. The results from this research can also be used as a foundation for developing programs and coaching regarding increasing leader-member exchange.

\subsection{Paper Structure}

The rest of the paper is organized as follows. Section 2 introduces the methodology used in this paper, which includes participants, measurement instruments, and also the descriptive and interpretive results of this research. Then, the paper will be concluded and presents direction for future researches.

\section{METHODOLOGY \& RESULT}

This research studied 240 employees in Bank X (including 3 branch managers, 44 sub-branch managers, and 193 staff), which got paired into the amount of 149 pairs of leadersubordinate. Each pair consists of 1 leader and 1 subordinate. The positions that are considered as leader are branch manager and sub-branch manager level, meanwhile the position that is considered as subordinate is staff level. The youngest age in the group of participants is 22 years old $(1.3 \%)$, and the oldest age is 55 years old $(0.7 \%)$. The shortest working period from participants is $<1$ month, meanwhile the longest working period is 108 months (9 years). The measurement instrument used to measure leader-member exchange is LMX-7 [29], and the measurement instrument used to measure job satisfaction is Job Satisfaction Measurement Scale [9].

\subsection{Descriptive Result of Job Satisfaction}

The average score for participants in Bank $\mathrm{X}$ is 1.95 ( $\mathrm{SD}=$ 1.45 ), with the minimum score of -2.15 and maximum score 5.67. For each dimension, the average score for intrinsic reward is 2.080, the average score of organizational extrinsic rewards is 1.695 , social extrinsic rewards is 4.017 , and the average score of convenience extrinsic costs is 0.003 .

The average interval of Job Satisfaction Measurement Scale [30] is between -2.5 until 2.5. The average score of intrinsic rewards, organizational extrinsic rewards, and convenience extrinsic cost falls in the average score interval. Meanwhile, social extrinsic rewards is considered as a high level. In conclusion, subordinate's in Bank X experience job satisfaction in all of its aspects, which are social extrinsic rewards, intrinsic rewards, organizational extrinsic rewards, and convenience extrinsic cost.

\subsection{Descriptive Result of Leader-Member Exchange}

The average score of leader-member exchange is $3.66(\mathrm{SD}=$ 0.417 ), with the minimum score of 3 and maximum score of 5. The average score of leader-member exchange is higher than the average score criteria, 3. In other words, participants (leaders and subordinates in Bank X) perceive a high level of leader-member exchange.

\subsection{Correlation between Leader-Member Exchange and Job Satisfaction}

Based on data tested on Smart PLS (statistic software), we found that the direct impact of leader-member exchange towards job satisfaction is significantly correlated, with coefficient 0.363 ( $\mathrm{p}<0.001)$. In conclusion, leader-member exchange has an impact on job satisfaction on employees of Bank X.

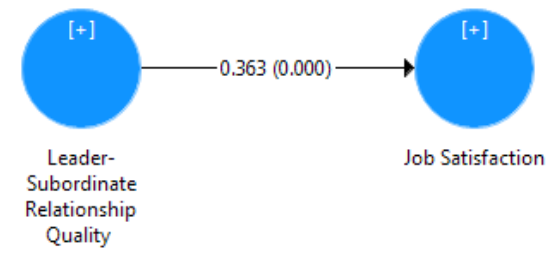

Picture 1 Correlation value and $\mathrm{P}$ value on correlation from leader-member exchange towards job satisfaction

\subsection{Correlation between Leader-Member Exchange and Job Satisfaction's Dimensions}

We tested the correlation between leader-member exchange and dimensions of job satisfaction, which can be seen in the picture below.

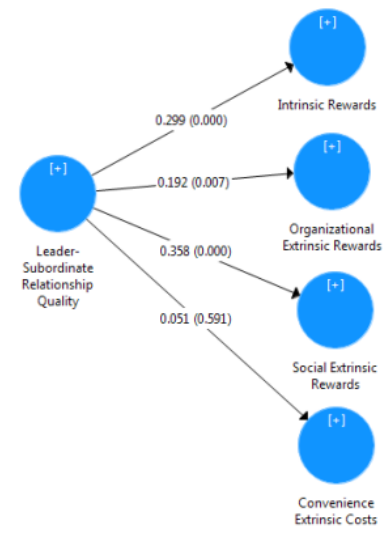


Picture 2 Correlation value and $\mathrm{P}$ value on correlation from leader-member exchange towards dimensions of job satisfaction

The result indicates that leader-member exchange significantly correlates with many dimensions of job satisfaction, which are social extrinsic rewards, intrinsic rewards, organizational extrinsic rewards. The impact of leader-member exchange towards job satisfaction's dimensions are listed as follows: intrinsic rewards (0.299, $\mathrm{p}<0.001)$, organizational extrinsic rewards $(0.192, \mathrm{p}<0.01)$, and social extrinsic reward $(0.358, \mathrm{p}<0.001)$. Meanwhile, convenience extrinsic costs dimension does not correlate significantly with leader-member exchange $(0.051$, $\mathrm{p}>0.05$ ). In other words, employees in Bank X perceive leader-member exchange to have an impact on dimensions of intrinsic rewards, organizational extrinsic rewards, and social extrinsic rewards, but does not have impact on convenience extrinsic costs.

\subsection{Descriptive Result of Job Satisfaction's Urgency and Reality Values}

Job Satisfaction Measurement Scale [30] identifies the level urgency and reality values perceived by each individual employee. Urgency value shows how important a certain aspect is for the employee, meanwhile the reality value shows how much that aspect is present and fulfilled in the employee's working experience. We summarized the collective urgency and reality values based on the employee's answer on the Job Satisfaction Measurement Scale [30].

Table 1 Description of job satisfaction's urgency and reality value

\begin{tabular}{clcc} 
No. & \multicolumn{1}{c}{$\begin{array}{c}\text { Vab Satisfaction } \\
\text { Dimensions }\end{array}$} & Urgency & Reality \\
\hline 1 & Intrinsic Rewards & 2.91 & 0.58 \\
2 & $\begin{array}{l}\text { Organizational } \\
\text { Extrinsic Rewards }\end{array}$ & 3.42 & 0.38 \\
3 & $\begin{array}{l}\text { Social Extrinsic } \\
\text { Rewards }\end{array}$ & 3.29 & 1.13 \\
4 & $\begin{array}{l}\text { Convenience Extrinsic } \\
\text { Costs }\end{array}$ & 3 & 0.01 \\
\hline
\end{tabular}

In other words, dimensions of job satisfaction that has the highest level of urgency value for Bank X's employees are: (a) organizational extrinsic rewards and social extrinsic rewards. On the other hand, the dimensions that has the highest level of reality value are social extrinsic rewards and intrinsic rewards.

\section{CONCLUSION}

Based on the results, we can discuss conclusions about: (a) impact of leader-member exchange towards job satisfaction; and (b) impact of leader-member exchange towards dimensions of job satisfaction. Leader-member exchange has an impact of job satisfaction with a correlation of $0.363(p<0.001)$. Dimensions of job satisfaction that correlates most strongly with leader-member exchange are: (a) social extrinsic rewards $(0.358, \mathrm{p}<0.001)$; (b) intrinsic rewards $(0.299, \mathrm{p}<0.001)$; and $(\mathrm{c})$ organizational extrinsic rewards $(0.192, \mathrm{p}<0.001)$.

The research's result can be used to comprehend researches in psychology (human resources) major, specifically about bank firms. Future researches can focus on the working culture in a bank, and the comparison of further individual characteristics such as culture, gender, nationality, work position, and participant's living context. Other than that, this result can be used as a foundation to develop other factors and dimensions of job satisfaction, and for the development of decent and effective intervention for bank employees. Furthermore, future researches can focus on organizational extrinsic rewards dimension with higher reliability value.

For further researches, methodology can also be improved by making the participants data anonymous, which enables them to answer more honestly, and minimizing the possibility of social desirability bias.

\section{ACKNOWLEDGMENT}

This work was supported by Fakultas Psikologi Universitas Tarumanagara and Lembaga Penelitian dan Pengabdian kepada Masyarakat (LPPM).

\section{REFERENCES}

[1] Direktur Publikasi dan Administrasi. Statistik Perbankan Indonesia Agustus 2015. Retrieved from https://www.bi.go.id/id/statistik/perbankan/indonesia/pa ges/spi_0815.aspx

[2] S. Y. Kusumastuti, "Derajat persaingan industri perbankan Indonesia: Setelah krisis ekonomi." Jurnal Ekonomi dan Bisnis Indonesia, vol. 23 no. 1, pp. 29 -42, 2008.

[3] M. O. A. Bushara, S. M. E., Ahmed and S. A. M. A., Elzebair, "Perceived service quality and customer satisfaction in banking performance: An empirical study in Sudanese agricultural bank, Wad Medani Branch, Sudan”. GSL Journal of Banking and Finance, vol. 1 no. 1, pp. 101, 2015 
[4] S. Papathanasiou, P. Mylonas, and D. Kenourgios, "Bank mergers - takeovers and customer satisfaction: The case of a Greek commercial bank". International Journal of Finance, Economics \& Trade, vol. 2, no. 2, pp. 11-17, 2018.

[5] M. U. Raza, A. Adeel, M. Nazam, R. S. I. Akash, M. Hashim, J. Ahmad, and M. I. Khan, "Impact of individual and professional aspects of employee behavior on customer satisfaction: Empirical evidences from Paskitani banking sector". International Transaction Journal of Engineering, Management, \& Applied Sciences \& Technologies, vol. 10 no. 4, pp. 489500, 2019

[6] G. M. Ramadhan, "The influence of social stressors on job performance with the role of strain as mediator in BTN Bogor". AL-INFAQ: Jurnal Ekonomi Islam, vol. 8 no. 1, pp. 52-78, 2017

[7] E. A. Locke, "What is job satisfaction?". Organizational behavior and human performance, vol. 4, 309-336, 1969.

[8] F. Luthans, B. C. Luthans, and K. W. Luthans, Organizational behavior: An evidence-based approach. Charlotte, North Carolina: Information Age Publishing, 2015.

[9] P. T. Y. S. Suyasa, "Job satisfaction measurement: The alternative method." in Paper presented on International Conference of Industrial and Organizational (IC IOP). Yogyakarta, August 9th-11 $1^{\text {th }}$, 2007

[10] N. Hoboubi, A. Choobineh, F. K. Ghanavati, S. Keshavarzi and A. A. Hosseini, "The impact of job stress and job satisfaction on workforce productivity in an Iranian petrochemical industry". Safety and health at work, vol. 8, pp. 67-71, 2017

[11] A. R. Zablah, B. D. Carlson, D. T. Donavan, J. G. Maxham, and T. J. Brown, "A cross-lagged test of the association between customer satisfaction and employee job satisfaction in a relational context". Journal of Applied Psychology, vol. 101 no. 5, 743-755. doi:10.1037/apl0000079, 2016

[12] P. Lee, M. T. Miller, T. A. Kippenbrock, C. Rosen, \& J. Emory. "College nursing faculty job satisfaction and retention: A national perspective". Journal of Professional Nursing, vol. 33 no. 4, pp. 261-266. doi:10.1016/j.profnurs.2017.01.001, 2017

[13] K. P. McIntyre, B. A. Mattingly, G. W. Lewandowski, and A. Simpson, "Workplace selfexpansion: Implications for job satisfaction, commitment, self-concept clarity, and self-esteem among the employed and unemployed". Basic and Applied Social Psychology, vol. 36 no. 1, pp. 59-69. doi:10.1080/01973533.2013.856788, 2014

[14] Hamidah, M. Mukhtar, and N. Karniati, "The effect of person-organization fit, job satisfaction, and trust toward high schools' teachers affective commitment". Indonesian Journal of Educational Review, vol. 4 no. 1, pp. $26-38,2017$

[15] S. Diestel, J. Wegge, and K. H. Schmidt, "The impact of social context on the relationship between individual job satisfaction and absenteeism: The roles of different foci of job satisfaction and work-unit absenteeism". Academy of Management Journal, vol. 57 no. 2, pp. 353-382. doi:10.5465/amj.2010.1087, 2014

[16] W. Fu, "The impact of emotional intelligence, organizational commitment, and job satisfaction on ethical behavior of Chinese employees". Journal of Business Ethics, vol. 122 no. 1, pp. 137-144. doi:10.1007/s10551-013-1763-6, 2013

[17] J. Lo Iacono, S. K. Weaven, \& D. Griffin, "Examination into the effects of job satisfaction on salesperson deviance: The moderating role of customer orientation". Journal of Business Economics and Management, vol. 17 no. 2, pp. 173-186. doi:10.3846/16111699.2015.1046399, 2016

[18] R. Loi, K. W. Chan, and L. W. Lam, "Leadermember exchange, organizational identification, and job satisfaction: A social identity perspective". Journal of Occupational and Organizational Psychology, vol. 87 no. 1, pp. 42-61. doi:10.1111/joop.12028, 2013

[19] C. Robert, T. C. Dunne, and J. Iun, "The impact of leader humor on subordinate job satisfaction: The crucial role of leader-subordinate relationship quality". Group \& Organization Management, pp. 1-32. DOI: 10.1177/1059601115598719, 2015

[20] M. Flickinger, M. Allscher, and M. Fiedler, "The mediating role of leader-member exchange: a study of job satisfaction and turnover intentions in temporary work". Human Resource Management Journal, vol. 26 no. 1, pp. 46-62. doi:10.1111/1748-8583.12091, 2016

[21] G. B. Graen, and T. A. Scandura, "Toward a psychology of dyadic organizing". Research in Organizational Behavior, vol. 9, pp. 175-208, 1987.

[22] V. Murphy-Berman, and J. J. Berman, Crosscultural differences in perceptions of distributive justice. Journal of Cross-Cultural Psychology, vol. 33 no. 2, pp. 157-170. doi:10.1177/0022022102033002003, (2002). 
[23] A. E. Roth, V. Prasnikar, M. Okuno-Fujiwara, and S. Zamir, "Bargaining and market behavior in Jerusalem, Ljubljana, Pittsburgh, and Tokyo: An experimental study". The American Economic Review, vol. 81 no. 5, pp. 1068-1096, 1991.

[24] L. A.Witt, "Equal opportunity perceptions and job attitudes". The Journal of Social Psychology, 131(3), 431-433. doi:10.1080/00224545.1991.9713869, 1991.

[25] A. Bakhsi, K. Kumar, and E. Rani, "Organizational justice perceptions as predictor of job satisfaction and organization commitment". International Journal of Business and Management, vol. 4 no. 9, pp. 145-154, 2009

[26] Price, J., \& Mueller, C. (1981). A causal model of turnover for nurses. Academy of Management Journal, 34, 543-565.

[27] C. Cammann, M. Fichman, and D. T. Jenkins, "The Michigan Organizational Assessment Questionnaire". Unpublished Manuscript, University of Michigan, Ann Arbor, MI., 1979

[28] P. F. Wernimont, "Intrinsic and extrinsic factors in job satisfaction". Journal of Applied Psychology, vol. 50 no. 1, pp. 41-50.doi:10.1037/h0022938, 1966

[29] G. B. Graen, and M. Uhl-Bien, "Relationship-based approach to leadership: Development of leader-member exchange (LMX) theory of leadership over 25 years: Applying a multi-level multi-domain perspective". The Leadership Quarterly, vol. 6 no. 2, pp. 219-247. doi:10.1016/1048-9843(95)90036-5, 1995

[30] J. Park, H. Chae, and H. J. Kim, "When and why high performers feel job dissatisfaction: A resource flow approach". Social Behavior and Personality: an international journal, vol. 45 no. 4, 2017,

[31] R. Cropanzano, and M. S. Mitchell, "Social exchange theory: An interdisciplinary review". Journal of Management, vol. 31 no. 6, pp. 874-900. doi:10.1177/0149206305279602, 2005

[32] G. C. Homans, "Social behavior as exchange". American Journal of Sociology, vol. 63 no. 6, pp. 597606, 1958

[33] A. J., Dubrin, Interpersonal job-oriented skills (11th ed.). New Jersey: Prentice Hall. 2012. 